\title{
ANALISIS KOEFISIEN PEKERJAAN PEMBESIAN PADA KONSTRUKSI GEDUNG BERTINGKAT
}

\author{
Eric Leonardy ${ }^{1}$ dan Jane Sekarsari ${ }^{2}$ \\ ${ }^{1}$ Program Studi Sarjana Teknik Sipil, Universitas Tarumanagara, Jl. Letjen S. Parman No.1 Jakarta \\ Eric.325160113@stu.untar.ac.id \\ ${ }^{2}$ Program Studi Sarjana Teknik Sipil, Universitas Tarumanagara, Jl. Letjen S. Parman No.1 Jakarta \\ Tamtana.js@gmail.com
}

Masuk: 18-07-2020, revisi: 08-08-2020, diterima untuk diterbitkan: 02-11-2020

\begin{abstract}
Accurate estimate is very necessary before a project run. The goals get a time and money efficiency with good quality. Cost estimation has an important element, namely the coefficient value. There are often problems in calculating prices caused by coefficient values. This study was conducted to find out whether the will gain better than the reference coefficient values in SNI 7394-2008 and PermenPUPR28-2016. Data is taken from 2 studies that discuss the iron fabricating. Processing data into coefficient values using a method known as Time motion and Study, and the calculation get the results that study A has a coefficient ratio of $22,86 \%$ and $11,43 \%$ in SNI 73942008 and PermenPUPR28-2016 while study B gets a coefficient comparison of 468,57\% and 234,29\% in SNI 73942008 and PermenPUPR28-2016. This happens because of the effect of worker productivity and the number of workers used on the data from each study. The results can be concluded that calculating the coefficient value of workers recommended to be done. This is to know whether the coefficient of workers used is more efficient than the coefficient values from references, because the coefficient of workers are not always better than the coefficients in the references.
\end{abstract}

Keywords: Coefficient value; Cost Estimation; PermenPUPR28-2016; Productivity; SNI7394-2006

\begin{abstract}
ABSTRAK
Melakukan estimasi yang akurat adalah sangat perlu sebelum suatu proyek akan berjalan. Tujuannya mendapatkan biaya yang kecil, waktu yang cepat, dan mutu yang baik agar proyek berjalan tanpa hambatan. Estimasi biaya memiliki elemen penting, yaitu nilai koefisien. Namun sering terjadi permasalahan pada perhitungan harga yang disebabkan nilai koefisien. Maka studi dilakukan untuk mengetahui apakah nilai koefisien dai pekerja yang digunakan akan menghasilkan nilai yang lebih baik dibandingkan nilai koefisien acuan pada SNI7394-2008 dan PermenPUPR28-2016. Data diambil dari 2 studi yang membahas mengenai pekerjaan pembesian. Kemudian pengolahan data produktivitas menjadi nilai koefisien menggunakan metode yang dikenal dengan Time motion and Study, dan hasil perhitungan mendapatkan hasil bahwa studi A memiliki perbandingan koefisien 22,86\% dan 11,43\% pada SNI7394-2008 dan PermenPUPR28-2016 sedangkan studi B mendapatkan perbandingan koefisien 468,57\% dan 234,29\% pada SNI7394-2008 dan PermenPUPR28-2016. Hal ini terjadi karena pengaruh produktivitas pekerja dan jumlah pekerja yang digunakan pada data dari tiap studi. Hasil perhitungan dapat disimpulkan bahwa melakukan perhitungan nilai koefisien pekerja sangat disarankan untuk dilakukan. Hal ini untuk mengetahui apakah nilai koefisien pekerja yang digunakan lebih efisien dibandingkan nilai koefisien dari acuan yang sudah ada, karena koefisien pekerja yang digunakan belum tentu lebih baik dibandingkan koefisien pada acuan SNI7394-2006 dan PermenPUPR28-2016.
\end{abstract}

Kata Kunci: Nilai Koefisien; Estimasi Biaya; PermenPUPR28-2016; Produktivitas; SNI7394-2006

\section{PENDAHULUAN}

Melakukan estimasi yang akurat adalah hal yang sangat perlu sebelum suatu proyek akan berjalan. Karena dengan adanya estimasi yang tepat akan bisa dilakukannya kontrol biaya yang minim, kontrol waktu yang dapat dipercepat, dan mutu pekerjaan yang baik. Mengontrol biaya yang minim dilakukan agar kita dapat mengontrol jug sumber daya yang akan kita gunakan dalam proyek yang akan berjalan, karena sumber daya merupakan faktor penentu keberhasilan dalam proyek konstruksi. Namun terdapat banyak sumber daya yang dimaksud, yaitu; manusia, material, mesin, uang, dan metode. Agar estimasi yang akurat dalam efisiensi biaya maka dilakukan studi analisis 
koefisien pekerja pada pekerjaan pembesian. Karena dalam merencanaakan anggaran suatu proyek diperlukan analisis sebagai pedoman dalam perhitungan rancangan anggaran biaya. Cara untuk menganalisis koefisien tersebut dengan mengolah data produktivitas dari para pekerja yang akan digunakan pada proyek. Namun pekerja yang didalam proyek memiliki keahlian masing-masing. Tujuan studi ini adalah untuk menganalisis koefisien dari data yang ditinjau dan akan dibandingkan dengan SNI 7398-2008 dan Permen PUPR 28-2016 untuk mengetahui apakah koefisien dari data yang diolah menghasilkan koefisien yang lebih baik daripada kedua pedoman yang telah dibuat dengan menggunakan metode time motion and study dalam pengolahan data waktunya.

Masalah utama dari studi ini adalah mengetahui hasil nilai koefisien dari data yang diolah kemudian di bandingkan dengan nilai koefisien pekerjaan pembesian yang ada di acuan (SNI 7398-2006 dan PermenPUPR 28-2016)

Tujuan utama dari penelitian ini adalah mengetahui apakah nilai perbandingan Nilai koefisien dari data yang di proses akan menghasilkan nilai koefisien yang lebih baik daripada acuan SNI dan PermenPURP.

\section{Manajemen proyek}

Manajemen proyek adalah suatu ilmu pengetahuan dalam segi memimpin organisasi yang didalamnya terdiri atas kegiatan perencanaan, pengorganisasian pelaksanaan dan pengendalian terhasap sumber daya yang terbatas dalam pencapaian sasaran dan tujuan yang diinginkan. Manajemen adalah melakukan pengelolaan sumber daya yang tersedia untuk mencapai tujuan organisasi secara efisiendan efektif dengan memperhatikan kesempatan yang ada serta memperhtungkan resiko/ hambatan yang dihadapi, manajemen adalah fungsi yang dilakukan oleh manajer (Sekarsari). Menurut (Soeharto) untuk mendapatkan 3 tujuan dari manajemen proyek secara tepat yaitu:

- Anggaran manajemen proyek yang dilakukan harus mendapatkan nilai biaya yang harus dikeluarkan sesuai dengan anggaran awal yang telah disetujui

- Spesifikasi manajemen proyek dilakukan untuk mendapatkan hasil kegiatan proyek sesuai dengan spesifikasi yang telah ditetapkan

- Waktu sebagai salah satu sasaran utama proyek agar tepat waktu, keterlambatan yang terjadi dapat menyebabkan kerugian bagi berbagai pihak dalam satu proyek seperti penambahan biaya, kehilangan kesempatan produk memasuki pasar.

\section{Manajemen biaya}

Berdasarkan (Cartlidge) Manajemen biaya adalah tanggung jawab dari quantity surveyor untuk menyediakan waktu dan biaya yang akurat dari sutau proyek ke beberapa variasi organisasi termasuk klien dan arsitek.manajemen biaya terbagi menjadi beberapa bagian yaitu:

- Cost planning: perencanaan biaya dikenal dari tahun 1970 dan dirancang dalam upaya memperkenalkan ketelitian dan akurasi kedalam proses penetapan biaya pra-kontrak.

- Cost control: biaya perencanaan hanya setengah dari cerita. Setelah proyek dimulai di lokasi, ada kebutuhan untuk mengendalikan tarkget biaya ditetapkan dalam fase prakontrak untuk memastikan bahwa biaya tidak lepas kendali.

- Cost analysis: perencanaan biaya proyek baru tergantung pada informasi biaya yang akurat dan terdokumentasi dengan baik. Analisis biaya adalah proses menganalisis dan merekam data biaya proyek setelah informasi tender diterima.

\section{Rancangan anggaran biaya}

Rancangan anggaran biaya mrmiliki pengertian perhitungan dari jumlah biaya yang akan diestimasi yang diperlukan dalam penggunaan bahan dan upah, juga biaya lainnya yang digunakan uintuk pelaksanaan bangunan atau proyek. Rancangan anggaran biaya pun terbagi dua yaitu; Rancangan anggaran biaya kasar dan rancangan anggaaran biaya terperinci. Adapun komponen-komponen yang menyusunnya, yakni;

- Komponen biaya langsung: Biaya bahan/material yang digunakan untuk proses pelaksanaan konstruksi, yang sudah memasukan biaya angkutan, biaya loading dan unloading; upah tenaga kerja adalah biaya yang dibayarkan kepada pekerja dalam menyelesaikan suatu jenis pekerjaan sesuai dengan keterampilan dan keahliannya; Biaya peralatan yang diperlukan untuk kegiatan sewa, pengangkutan, pemasangan alat, memindahkan, membongkar dan biaya operasi, juga dapat dimasukan upah dari operator mesin dan pembantunya.

- Komponen Biaya tidak langsung: Overhead umum biasa tidak dapat segera dimasukan ke suatu jenis pekerjaan dalam proyek itu; overhead proyek adalah biaya yang dapat dibebankan kepada proyek tetapi tidak dapat dibebankan kepada biaya bahan-bahan, upah tenaga kerja atau biaya alat-alat; profit adalah keuntungan yang didapat oleh pelaksana kegiatan proyek sebagai nilai imbal jasa dalam proses pengadaan proyek yang 
sudah dikerjakan; dan pajak adalah berbagai macam pajak seperti PPN, PPH dan lainnya atas hasil operasi perusahaan

\section{Manajemen sumber biaya}

Kekuatan sumber daya manusia dalam suatu organisasi semakin disadari keberadaannya sehingga manusia dipandang sebagai asset terpenting dari berbagai sumber daya dalam organisasi. Kuatnya posisi manusia dalam organisasi melebihi sumberdaya lainnya seperti material, metode, uang, mesin, pasar sehingga mendorong para ahli memberi sumbangan teori tentang manajemen sumber daya manusia.

Banyak indikator penting yang berhubungan dengan manajemen sumber daya manusia, yaitu;

- Aktivitas yang berhubungan dengan memberdayakan manusia dalam organisasi.

- Pendekatan strategis dengan cara-cara terbaik dan proaktif dalam mengelola sumber daya organisasi.

- Berkenaan dengan nilai dan kultur organisasi dan tidak hanya menciptakan aspek-aspek yang rasional dan nyata seperti struktur dan teknologi, juga pencipta ideologi, bahasa, kepercayaan.

- Berkaitan dengan bagaimana merencanakan, menempatkan, mengkoordinasi, membina, memotivasi dan mengontrol sumber daya manusia yang bekerja dalam organisasi.

\section{Produktivitas}

Produktivitas adalah sikap mental yang berpandangan bahwa kehidupan hari ini lebih baik dari kemarin dan besok lebih baik dari hari ini. Dan juga perbandingan antara hasil yang dicapai (output) dengan keseluruhan sumber daya yang digunakan (input). Produktivitas sendiri memiliki pengertian yang sangat luas, pengertiannya lebih luas dari ilmu pengetahuan, teknologi dan manajemen yaitu sebagai suatu sikap mental yang timbul dari motivasi yang kuat dari masyarakat yang secara terus menerus berusaha meningkatkan kualitas kehidupan. Terdapat juga variabel yang mempengaruhi produktivitas yaitu;

- Kondisi fisik lapangan dan sarana bantu: kondisi fisik geografis lokasi proyek, tempat penampungan tenaga kerja yang terawat serta sarana bantu yang berupa peralatan konstruksi amat berpengaruh terhadap produktivitas tenaga kerja.

- Pengawasan, perencanaan dan koordinasi: pengawasan adalah segala sesuatu yang berhubungan langsung dengan tugas pengelolaan para tenaga kerja, memimpin pekerja dalam melaksanakan tugas dan menjabarkan perencanaan dan pengendalian.

- Komposisi kelompok kerja: yang dimaksud adalah perbandingan jam-orang pengawas dengan pekerja yang dipimpinnya, dan perbandingan jam-orang untuk disiplin-disiplin kerja dalam kelompok kerja.

- Kerja lembur: terjasi untuk mengejar sasaran jadwal

- Ukuran besar proyek: penelitian menunjukan bahwa besar proyek akan mempengaruhi produktivitas tenaga kerja lapangan. Semakin besar ukuran proyek produktivitas proyek akan menurun.

- Pekerja langsung versus subkontrak: Dikenal diacara bagi konstraktor utama dalam melaksanakan pekerjaan lapangan, yaitu dengan merekrut langsung tenaga kerja dan menyerahkan kepada pengawas atau menyerahkan paket kerja tertentu kepada subkontraktor.

- Kurva pengalaman: bila seseorang melakukan pekerjaan yang identik berulang kali maka dapat diharapkan akan terjadi pengurangan jam pertenaga kerja atau biaya untuk menyelesaikan pekerjaan. Sehingga dapat dikatakan produktivitas naik akibat pengalaman dan peningkatan keterampilan.

\section{Motion time and study}

Motion time and study adalah berbagai prosedur yang digunakan untuk mengetahui durasi yang dibutuhkan seorang operator untuk menyelesaikan suatu kegiatan tertentu. Prosedur yang digunakan adalah standard time yang dikembangkan untuk membantu pengamat dalam menentukan waktu yang dibutuhkan operator untuk menyelesaikan pekerjaannya baik secara keseluruhan maupun tiap-tiap elemen pekerjaan. Kecepatan dari seorang bekerja selama studi waktu disesuaikan dengan peringkatnya dalam mengerjakan suatu pekerjaan dengan waktu normal. Waktu yang diacatat berdasarkan peringkat kinerja pekerja yang disebut dengan waktu normal atau normal time. Dapat dilihat pada persamaan berikut:

$$
\text { Waktu Normal }=\text { Waktu pengamatan }+(\text { waktu pengamatan } x \text { peringkat })
$$

Dengan peringkat dapat dilihat pada Tabel 1 berikut. 
Tabel 1. Faktor pengukuran peringkat kerja

\begin{tabular}{cccccc}
\hline \multicolumn{3}{c}{ SKILL } & \multicolumn{3}{c}{ EFFORT } \\
\hline$+0,15$ & A1 & Superskill & $+0,13$ & A1 & Excessive \\
$+0,13$ & A2 & & $+0,12$ & A2 & \\
$+0,11$ & B1 & Excellent & $+0,10$ & B1 & Exellent \\
$+0,08$ & B2 & & $+0,08$ & B2 & \\
$+0,06$ & C1 & Good & $+0,05$ & C1 & Good \\
$+0,03$ & C2 & & $+0,02$ & C2 & \\
0,00 & D & Average & 0,00 & $\mathrm{D}$ & Average \\
$-0,05$ & E1 & Fair & $-0,04$ & E1 & Fair \\
$-0,10$ & E2 & & $-0,08$ & $\mathrm{E} 2$ & \\
$-0,16$ & F1 & Poor & $-0,12$ & $\mathrm{~F} 1$ & Poor \\
$-0,22$ & F2 & & $-0,17$ & $\mathrm{~F} 2$ & \\
\hline \multicolumn{3}{c}{ Conditions } & \multicolumn{3}{c}{ Consistency } \\
\hline$+0,06$ & $\mathrm{~A}$ & Ideal & $+0,04$ & $\mathrm{~A}$ & Perfect \\
$+0,04$ & $\mathrm{~B}$ & Excellent & $+0,03$ & $\mathrm{~B}$ & Excellent \\
$+0,02$ & $\mathrm{C}$ & Good & $+0,01$ & $\mathrm{C}$ & Good \\
0,00 & $\mathrm{D}$ & Average & 0,00 & $\mathrm{D}$ & Average \\
$-0,03$ & $\mathrm{E}$ & Fair & $-0,02$ & $\mathrm{E}$ & Fair \\
$-0,07$ & $\mathrm{~F}$ & Poor & $-0,04$ & $\mathrm{~F}$ & Poor \\
\hline
\end{tabular}

(Sumber: Barnes 289)

Kelonggaran yang diijinkan untuk pekerja dalam mengerjakan suatu pekerjaan tetap diperhitungkan. Bagaimanapun dalam menyelesaikan suatu pekerjaan tidak bisa diharapkan seorang bekerja seharian tanpa terganggu. Pekerja memerlukan waktu untuk keperluan pribadinya. Dengan berbagai kondisi menunjukan bahwa dibutuhkan 5\% kelonggaran untuk waktu pribadi pekerja. Waktu normal yang ditambahkan dengan kelonggaran untuk waktu personal menjadikannya sebagai waktu standar untuk menyelesaikan suatu pekerjaan. Waktu standar dapat diperoleh pada persamaan berikut:

$$
\text { Waktu Standar }=\text { Waktu Normal }+(\text { Waktu normal } x \text { faktor toleransi })
$$

\section{Analisis harga satuan pekerjaan dan koefisien tenaga kerja}

Analisis harga satuan pekerjaan adalah perhitungan kebutuhan biaya tenaga kerja, bahan, dan peralatan untuk mendapatkan harga satuan atau satu jenis pekerjaan tertentu.dalam melakukan analisis harga satuan pekerjaan dibutuhkan suatu nilai koefisien. Koefisien yang dimaksud adalah factor pengali sebagai dasar perhitungan biaya upah tenaga kerja, biaya, alat, dan material. Oleh karena itu untuk satuan volume pekerjaan tertentu dapat dihitung koefisien kebutuhan tenaga kerja yang dirumuskan, berdasarkan Permen Pekerjaan Umum Nomor 11/PRT/M/2013, pada persamaan berikut:

$$
\text { Produksi / Hari }(Q T)=T k \times Q 1
$$

Untuk pekerjaan $1 \mathrm{~m}^{2}$

$$
\text { Pekerja }=\frac{(T k \times P)}{Q T}
$$

Dengan Tk = jumlah jam kerja efektif 1 hari $(7$ jam $), \mathrm{P}=$ jumlah pekerja yang diperlukan, $\mathrm{Q} 1=$ Produktivitas ( $\mathrm{m}^{2} /$ waktu pekerjaan).

\section{Pekerjaan besi}

Pekerjaan besi dalam suatu proyek konstruksi memegang peranan yang sangat penting karena pekerjaan besi akan mempengaruhi pekerjaan beton bertulang. Dimana pekerjaan besi yang sesuai dengan metode pelaksanaan konstruksi. Dalam konstruksi beton bertulang, pada umumnya digunakan besi yang berpenampang bulat untuk tulangan utama maupun tulangan sekunder, karena dapat melekat kuat dalam beton. Lagipula cara pengerjaannya lebih sederhana dan ongkos pembuatannya lebih murah dibandingkan dengan ongkos pembuatan besi yang berpenampang lainnya. Besi yang umumnya dipakai dalam tulangan adalah besi dengan diameter $8,10,12,13,16,19,22,25,28,30,32,38,40,45 \mathrm{~mm}$. ada juga tulangan ulir yang kadangkala digunakan dalam pekerjaan konstruksi. Besi tersebut selain memiliki diameter yang berbeda-beda juga mempunyai tegangan tarik yang berbedabeda. Untuk tulangan besi polos yang berdiameter lebih kecil sama dengan $12 \mathrm{~mm}$ mempunyai tegangan Tarik 240 
mpa sedangkan untuk tulangan yang lebih besar 12mm mempunyai tegangan Tarik $400 \mathrm{MPa}$. Dari berbagai jenis tulangan besi yang ada, jenis-jenis tulangan besi ini dipakai sesuai dengan keperluan pekerjaan konstruksi.

\section{METODE PENELITIAN}

\section{Data penelitian}

Karena keadaan dunia yang memaksa kita melakukan pembatasan sosial berskala besar yang disebabkan oleh pandemic virus covid-19, maka studi ini memiliki banyak keterbatasan dan detail pada time motion and study. Maka data studi ini diambil dari studi terdahulu dengan judul:

- Studi A: Studi analisis koefisien tukang besi pada perhitungan harga satuan untuk rumah tinggal di Kawasan Jakarta dan sekitarnya.

- Studi B: Analisis produktivitas tenaga kerja di lapangan pada pekerjaan kolom.

\section{Pengumpulan data}

Data yang didapat dari tiap-tiap studi diambil dengan cara berikut:

- Studi A: Data hasil observasi meliputi ukuran diameter besi, ukuran bahan pengamatan, volume besi untuk keperluan kalibrasi dan menentukan koefisien tenaga kerja dari suatu pekerjaan besi yang terdiri dari pekerjaan memotong, membengkokan, membuat sengkang, dan merakit.

- Studi B: Dilakukan pengamatan langsung dilapangan. Dimulai pukul 08.00-12.00 kemudian dilanjutkan lagi pukul 13.00-16.00. Objek pengamatan dalam studi adalah pelaksanaan pekerjaan pembesian kolom, hasil pengamatan adalah volume pekerjaan yang dapat dikerjakan pada rentan waktu 7 jam tersebut. Pengamatan dilakukan 4 hari untuk pekerjaan pembesian.

\section{Koefisien tenaga kerja pembesian}

Pekerjaan yang meliputi memotong, membengkokan, membuat Sengkang adalah pekerjaan pembesian. Dan dalam menghitung koefisien tenaga kerja dibutuhkan data berupa waktu standar pekerjaan, berat, dan jumlah tenaga kerja.

Untuk mendapatkan waktu standar para pekerja dibutuhkan data waktu dari hasil pengamatan, lalu data waktu tersebut akan diolah dengan metode time motion and study dengan cara mengalikan data waktu tersebut dengan faktor peringkat kerja dari para pekerja dan akan menghasilkan waktu normal, waktu normal tersebut akan dikalikan Kembali 5\% sebagai faktor toleransi dari para pekerja dan akan menjadi waktu standar dari pekerjaan yang digunakan dalam perhitungan koefisien pekerjaan pembesian.

Setelah didapat waktu standar pekerjaan pembesian, selanjutnya dapat dihitung koefisien dari tenaga kerja pekerjaan pembesian. Menurut Undang-Undang No.13 tahun 2003 tentang Ketenagakerjaan pasal 77, 1 hari kerja efektif untuk para pekerja adalah 7 jam. memiliki satuan orang-jam/kg, sehingga perlu untuk mengubah satuannya menjadi oranghari/kg dengan membagi koefisien tenaga kerja tersebut dengan 7 jam. Sehingga koefisien tenaga kerja dapat dihitung sebagai berikut:

$$
\text { Koefisien pekerja (Orang }- \text { Hari) }=\frac{\text { Jumlahjamkerja } \times \text { JumlahPekerja }}{\text { Berat } x 7}
$$

Perhitungan koefisien tenaga kerja tersebut dihitung untuk setiap elemen struktur, sebanyak jumlah dari masingmasing elemen struktur yang diamati. Kemudian koefisien tenaga kerja tersebut dirata-rata, sehingga didapat nilai koefisien tenaga kerja yang dipakai untuk tiap elemen struktur yang diamati yaitu balok, dan kolom.

\section{HASIL DAN PEMBAHASAN}

\section{Hasil pengamatan}

Hasil pengamatan yang diambil dari studi A menghasilkan data seperti Tabel 2.

Tabel 2. Hasil pengamatan studi A

\begin{tabular}{cccc}
\hline Berat $(\mathrm{Kg})$ & Banyak Pekerja & Kegiatan & Waktu Pengamatan(Jam) \\
\hline 12,583 & 3 & Memotong & 0,079 \\
15,897 & 3 & Membuat Sengkang & 0,8 \\
29,626 & 1 & Membengkokkan & 0,095 \\
43,816 & 4 & Merakit & 0,578 \\
\hline
\end{tabular}

Hasil pengamatan yang diambil dari studi B menghasilkan data seperti Tabel 3 dibawah ini 
Tabel 3. Hasil pengamatan studi B

\begin{tabular}{cccc}
\hline Hari Ke & Banyak Pekerja & Volume Pekerjaan $(\mathrm{Kg})$ & Durasi \\
\hline 1 & 3 & 2353,14 & 7 \\
2 & 3 & 2747,73 & 7 \\
3 & 3 & 2289,777 & 7 \\
4 & 3 & 1831,82 & 7 \\
\hline (Sumber: Rizky, 2018$)$ & &
\end{tabular}

\section{Analisis data}

Setelah hasil pengamatan didapat, maka dapat dilakukan perhitungan dengan cara sebagai berikut.

- Studi A

\begin{tabular}{|c|c|c|}
\hline Waktu normal (Memotong) & $=(0,0792)+(0,0792 \times 0,12)$ & $=0,0887 \mathrm{jam}$ \\
\hline Waktu normal (Membuat Sengkang) & $=(0,7994)+(0,7994 \times 0,12)$ & $=0,7796$ jam \\
\hline Waktu normal (Membengkokan) & $=(0,0945)+(0,0945 \times 0,12)$ & $=0,1058 \mathrm{jam}$ \\
\hline Waktu normal (Merakit) & $=(0,5778)+(0,5778 \times 0,12)$ & $=0,6471 \mathrm{jam}$ \\
\hline \multicolumn{3}{|c|}{ Setelah waktu normal dihitung waktu standar seperti dibawah ini } \\
\hline Waktu standar (Memotong) & $=0.08871+(0.08871 \times 0.05)$ & $=0,0932 \mathrm{jam}$ \\
\hline Waktu standar (Membuat sengkang) & $=0.7796+(0.7796 \times 0.05)$ & $=0,9404 \mathrm{jam}$ \\
\hline Waktu standar (Membengkokan) & $=0.1058+(0.1058 \times 0.05)$ & $=0,1111 \mathrm{jam}$ \\
\hline Waktu standar (Merakit) & $=0.6471+(0.6471 \times 0.05)$ & $=0,6794 \mathrm{jam}$ \\
\hline
\end{tabular}

Total waktu standar yang dibutuhkan untuk menyelkesaikan pekerjaan $0,09315+0,9404+0,1111+0,6794$ $=1,824$ jam.

Dari perhitungan diatas menghasilkan Tabel 4 seperti di bawah.

Tabel 4. Rangkuman waktu normal dan waktu standar

\begin{tabular}{lcccc}
\hline \multicolumn{1}{c}{ Kegiatan } & Jumlah Pekerja & Volume Pekerjaan(Kg) & Waktu Normal(jam) & Waktu standar (jam) \\
\hline Memotong & 3 & 12,583 & 0,0887 & 0,0632 \\
Membuat Sengkang & 3 & 15,8965 & 0,7796 & 0,9404 \\
Membengkokan & 1 & 29,6256 & 0,1058 & 0,1111 \\
Merakit & 4 & 43,8159 & 0,6471 & 0,6794 \\
\hline
\end{tabular}

Lalu dilakukan perhitungan koefisien dari data waktu yang didapat dan data hasil pengamatan menghasilkan nilai koefisien seperti dibawah ini

Memotong

Koefisien pekerja (Orang-Hari) $=\frac{0,09315 \times 3}{12,583 \times 7}=0,003173 \mathrm{OH}$

Membuat Sengkang

Koefisien pekerja (Orang-Hari) $=\frac{0,940372 \times 3}{15,8965 \times 7} \quad=0,025353 \mathrm{OH}$

Membengkokan

Koefisien pekerja (Orang-Hari) $=\frac{0,111109 \times 1}{29,6256 \times 7} \quad=0,000536 \mathrm{OH}$

Merakit

Koefisien pekerja (Orang-Hari) $=\frac{0,6794 \times 4}{43,8159 \times 7} \quad=0,0038091 \mathrm{OH}$

Koefisien pekerja Pembesian $=0,003173+0,025353+0,000536+0,0038091=0,03287 \mathrm{OH}$

Sehingga didapatkan nilai koefisien pekerja pekerjaan pembesian $0.03287 \mathrm{OH} / \mathrm{Kg}$ lalu dikalikan 10 untuk menjadikannya satuan $\mathrm{OH} / 10 \mathrm{Kg}$ dan menghasilkan Nilai Koefisien $0.328 \mathrm{OH} / \mathrm{Kg}$

Perhitungan perbandingan SNI 7394-2008 Perhitungan perbandingan PermenPUPR 28-2016 $\frac{0,328}{0,07} \times 100 \%=468,57 \%$ $\frac{0,328}{0,14} \times 100 \%=234,29 \%$

- Studi B

Waktu normal $=(7)+(7 \times 0,12)=7,84$ jam

Setelah waktu normal dihitung waktu standar seperti dibawah ini

Waktu standar $=7,84+(7,84 \times 0,05)=8,232$ jam

Dari perhitungan waktu normal dan waktu standar menghasilkan Tabel 5 di bawah ini. 
Tabel 5. Rangkuman waktu normal dan waktu standar

\begin{tabular}{ccccc}
\hline Hari Ke & Banyak Pekerja & Volume Pekerjaan(Kg) & Waktu Normal(jam) & Waktu standar (jam) \\
\hline 1 & 3 & 2353,14 & 7,84 & 8,232 \\
2 & 3 & 2747,73 & 7,84 & 8,232 \\
3 & 3 & 2289,777 & 7,84 & 8,232 \\
4 & 3 & 1831,82 & 7,84 & 8,232 \\
\hline
\end{tabular}

Lalu dilakukan perhitungan koefisien dari data tabel diatas menghasilkan nilai seperti dibawah ini Hari ke -1

Koefisien pekerja (Orang-Hari) $=\frac{8,232 \times 3}{2353,14 \times 7}=0,0015 \mathrm{OH}$

Hari ke -2

Koefisien pekerja (Orang-Hari) $=\frac{8,232 \times 3}{2747,73 \times 7}=0,0013 \mathrm{OH}$

Hari ke -3

Koefisien pekerja (Orang-Hari) $=\frac{8,232 \times 3}{2289,77 \times 7}=0,0015 \mathrm{OH}$

Hari ke -4

Koefisien pekerja (Orang-Hari) $=\frac{8,232 \times 3}{1831,82 \times 7}=0,0019 \mathrm{OH}$

Dari perhitungan koefisien dirata-rata lalu dikalikan 10 agar menghasilkan data $\mathrm{OH} / 10 \mathrm{~kg}$ karena hasil dalam $\mathrm{OH} / \mathrm{Kg}$

Koefisien pekerja : $\frac{0,0015+0,0013+0,0015+0,0019}{4}=0,016 \mathrm{OH}$

Perhitungan perbandingan SNI 7394-2008

$\frac{0,016}{0,07} \times 100 \%=22,86 \%$

Perhitungan perbandingan PermenPUPR 28-2016

$\frac{0,016}{0,14} \times 100 \%=11,43 \%$

Dari hasil pengolahan data kedua studi dapat dirangkum hasilnya pada Tabel 6 di bawah ini.

Tabel 6. Rangkuman hasil perbandingan

\begin{tabular}{cccccc}
\hline & Nilai Koefisien & $\begin{array}{c}\text { Nilai Koefisien } \\
\text { SNI 7394-2008 }\end{array}$ & \multicolumn{3}{c}{ Nilai Koefisien } \\
& PermenPUPR 28-2016 & \\
\hline \multirow{2}{*}{ Studi A } & $\mathrm{OH} / 10 \mathrm{Kg}$ & $\mathrm{OH} / 10 \mathrm{Kg}$ & $\%$ & $\mathrm{OH} / 10 \mathrm{Kg}$ & $\%$ \\
\cline { 2 - 6 } & 0,328 & 0,07 & 468,57 & 0,14 & 234,29 \\
\hline \multirow{2}{*}{ Studi B } & $\mathrm{OH} / 10 \mathrm{Kg}$ & $\mathrm{OH} / 10 \mathrm{Kg}$ & $\%$ & $\mathrm{OH} / 10 \mathrm{Kg}$ & $\%$ \\
\cline { 2 - 6 } & 0,016 & 0,07 & 22,86 & 0,14 & 11,43 \\
\hline
\end{tabular}

\section{Pembahasan}

Dari tabel yang telah dirangkum diatas dapat dilihat perbandingan persentase pada nilai koefisien perumahan kosambi lebih besar 561,43\% dari nilai koefisien SNI 7394-2008 dan nilai koefisien pekerja perumahan kosambi lebih besar 187,14\% dari nilai koefisien PUPR 28-2016, hal ini disebabkan oleh produktivitas dari pekerja proyek perumahan kosambi yang kurang produktif dan menggunakan tenaga kerja ekstra dalam proyek perumahan tersebut. Namun tidak semua salah dari produktivitas pekerja perumahan kosambi, perbedaan nilai koefisien yang signifikan seperti ini dapat juga terjadi karena kesalahan dari data-data yang kurang lengkap, data pengamatan yang diambil kurang banyak, atau kelalaian surveyor pada saat pencatatan waktu pekerja yang banyak tidak tercatat pada saat pekerja melakukan pekerjaan. Perbedaan yang cukup signifikan ini dapat juga disebabkan oleh standar koefisien yang dipakai oleh SNI dan Permen PUPR rendah sebagai alasan untuk acuan seluruh wilayah di Indonesia. Atas dasar ini kementrian PUPR yang membuat acuan menentukan koefisien berdasarkan nilai yang dapat digunakan di seluruh wilayah Indonesia. Sehingga nilai ini bila digunakan di pulau Jawa, produktivitas lapangan akan lebih besar dibanding acuan tersebut. Acuan pun tidak menjelaskan metode pelaksanaan yang digunakan, sehingga nilai produktivitas bisa sangat beragam tergantung metode yang digunakan di lapangan. Dalam SNI 7398-2008 dan Permen PUPR 28-2016 diasumsikan metode pelaksanaan masih menggunakan metode konvensional. Pekerjaan seperti potong dan membengkokkan tulangan masih dengan cara konvensional. Proses mobilisasi untuk tulangan pun juga menggunakan alat konvensional.Penggunaan dua data dengan rentan perbedaan waktu yang berbeda untuk mengetahui bahwa dengan metode pengolahan data waktu yang sama akan menghasilkan perbedaan karena metode pelaksanaan yang sudah berbeda. Dan saat dibandingkan dengan SNI dan PUPR hasil Koefisien dari masing masing data tidak akan selalu lebih hemat dari pada koefisien pekerja dari SNI maupun PermenPUPR. 


\section{KESIMPULAN DAN SARAN}

\section{Kesimpulan}

Berdasarkan hasil analisis dan pembahasan yang telah dilakukan, maka pada studi kali ini dapat disimpulkan bahwa hasil dari perhitungan nilai koefisien dan perbandingannya dengan acuan (SNI 7394-2008 dan PermenPUPR 282016) adalah sebagai berikut:

- Hasil perbandingan Studi A menghasilkan nilai koefisien yang lebih besar bila dibandingkan dengan acuan nilai koefisien SNI 7394-2008 dan PermenPUPR 28-2016 sedangkan Studi B menghasilkan nilai koefisien yang lebih kecil bila dibandingkan dengan nilai koefisien acuan dari SNI 7394-2008 dan PermenPUPR 282016.

- Sebaiknya dilakukan analisis terlebih dahulu terhadap nilai koefisien dari para pekerja yang akan digunakan pada proyek lalu dibandingkan dengan nilai koefisien acuan pada SNI yang ada agar produktivitas para pekerjanya dapat di perhatikan demi kelancarannya suatu proyek.

- Perhitungan nilai Koefisien akan selalu berbanding terbalik dengan Produktivitas karena semakin besar produktivitas semakin kecil nilai koefisien yang didapat.

\section{Saran}

Berdasarkan hasil analisis dan pembahasan yang dilakukan ada beberapa saran yang dapat disampaikan:

- Kontraktor/perencana perlu memperhatikan produktivitas tenaga keranya karena dengan memperhatikan produktivitasnya maka pelaksanaan/ perencanaan dapat menjadi lebih efisien.

- Perhitungan koefisien tenaga kerja yang didapatkan merupakan hasil perhitungan dari 2 data proyek sehingga dapat dilakukan penelitian lebih lanjut dengan data yang lebih banyak dan lebih lengkap agar didapat nilai koefisien tenaga kerja yang dapat mewakili secara statistik yang kemudian dapat dijadikan sebagai acuan perhitungan biaya koefisien tenaga kerja pembesian di Indonesia.

\section{DAFTAR PUSTAKA}

Barnes, Ralph M. Motion and time study: Design and Measurement of Work. 7th Edition. Newyork: Willey and Son, 1980.

Cartlidge, Duncan. Quantity Surveyor's Pocket Book First Edition. Elsevier, 2009.

Peraturan mentri pekerjaan umum dan perumahan rakyat Republik Indonesia Nomor 22/PRT/M/2018. Mentri Pekerjaan Umum dan Perumahan Rakyat Republik Indonesia, 2018.

Pratama, Rizky Allam Zandriyan. "Analisis Produktivitas Tenaga Kerja Di Lapangan Pada Pekerjaan Kolom." Jurnal Teknik Sipil Fakultas Teknik dan Perencanaan Universitas Islam Indonesia (2018).

Sekarsari, Jane. Sistem Informasi Manajemen, Teori dan Konsep Aplikasi pada Sektor Konstruksi. Jakarta: Universitas Trisakti, 2018.

SNI 7394:2008 Tata cara perhitungan harga satuan pekerjaan beton untuk konstruksi bangunan gedung dan perumahan. Badan Standardisasi Nasional, 2008.

Soeharto, Iman. Manajemen Proyek (Dari Konseptual Sampai Operasional). Edisi Kedua. Jakarta: Erlangga, 1999. 